\title{
ZOO IN THE GARDEN: Book Review
}

Transforming Cultures eJ ournal,

Vol. 3 No 1, February 2008

http:// epress.lib.uts.edu.au/journals/TfC

\section{Jodi Frawley $^{1}$}

Zoo in the Garden (2005) Edward Hamilton Aitken. Permanent Black, Delhi. ISBN: 81-7824-121-8, (288 pages.)

Zoo in the Garden is part of the Lost and Found Wildlife Series and although available through Permanent Black in 2005, these stories were first published in the late nineteenth century. Edward Hamilton Aitken, affectionately known to his readership as EHA, was Indian born, but a thoroughly British subject. The son of a Scottish missionary, he was educated at the Bombay University, now known as Mumbai University. Aitken was a career public servant employed in the Customs and Salt Department of the Bombay Government, taking up posts in Khargoda and Karachi of the Bombay Presidency. Aitken delved into Natural History in his leisure time and like countless other Europeans, he was an amateur at a time when the disciplines of science where becoming institutionalised. Aitken was a founding member of the Natural History Society of Bombay in 1883 and his writings demonstrate this grey area between popular renditions of life lived through the lens of Natural History and the more formal aspects of Imperial science.

This book collects together two of the most popular of Aitken's texts. While stationed in Khargoda, he began a series of monthly articles in The Times of India, which came to be collected together as The Tribes on My Frontier (1883). The Common Birds of India was written as a shorthand record of the everyday birdlife encountered in the city of Bombay. As both 'books' were originally published in a newspaper format, Aitken opts for a style

\footnotetext{
${ }^{1}$ Jodi Frawley is a PhD student in Gender and Cultural Studies at the University of Sydney.
} 
and structure dictated by his publication forum. There are fifty two short articles that become the Zoo in the Garden, each one no more that four or five pages long.

In the first half of the book, Aitken's topic is The Tribes on My Frontier. Here he considers the animals that inhabit his daily life in 'Dustypore', a fictional district of Bombay. The stories he tells through the mosquitoes, frogs, bats, crows and butterflies provide a lyrical and entertaining account of life in India. What becomes apparent in this text is the way in which people are part of nature, that nature invades the homely and everyday spaces of urban life. Aitken's house and garden cannot be articulated as separate spheres in which he moves across one threshold into the other. Instead, through an understanding of the animals, nature is shown to be a series of relationships between humans and animals within this environment.

Indeed, exactly where Aitken locates the frontier of his title is not clear. Is it the house and garden divide, the human and animal, the urban and the country? Of course the reference to frontier and tribes in title also pay homage to the anthropological study of local groups of people by outsiders. In this regard, Aitken's position creates an anthropomorphic vision of the animals' emotions, relationships and actions. He finds bats that have 'family affection' (46), butterflies as 'ornaments' (69) and rats that behave as 'criminals' (10). However, even as he writes the difference between humans and animals he also shows how he was very much a part of the animal life of his local surroundings. He lived in a very connected way with the animals that he found in his backyard, co-habiting his living spaces, and those encountered as he traveled through this part of India.

The Common Birds of Bombay, which makes up the second part of the book, although structured in the same prose style, has a different sort of tone. Given that this book was produced to assist readers in the identification of local birds, each of these articles are heavier on description of the animals themselves and lighter on the anecdotes about life among the animals found in the first section. Here Aitken shifts the reference points for his writing into a more formal scientific intertextuality. Expert authors Thomas Jerdon, The Birds of India (1862-4); H Edwin Barnes The Birds of India (1897) and Eugene W. Oates The Fauna of British India (1890) mark out the terms of reference for Aitken in writing about the common birds of Bombay. Aitken concerns himself with living 
animals and not museum specimens thus differentiating himself from these men of science. In this way Aitken provides a conduit between the expert scientist and his inexpert audience of readers.

These writings by a British subject living in India are also imbricated with colonial attitudes to environment of that time. In advocating the impossibility of keeping fowls as pets he articulates his relation to the Poultry Yard as follows: 'It is pleasant to have a large establishment of dependents about you, looking for protection and maintenance. It imparts a certain patriarchal, Abrahamic magnificence to your conception of yourself' (110). The metaphors with which Aitken structures his text also structured the life he led in the Bombay presidency. This attitude to animals under his care reflects his complicity in the process of colonialism. Aitken saw himself in a hierarchical relation to the animals and nature around him, and the dependence of his companion animals enhanced his self identity as both patriarchal and belonging to a Judeo-Christian tradition. Both these factors were central to the culture and governance of the British Empire, here demonstrated at an everyday level by an everyday subject about everyday living. As a sympathetically rendered character in the colonial story, this work demonstrates the ambiguity and ambivalence of those caught between the worlds of the everyday and the larger schemata to which they also belong. The reprinting of these two works in the one volume brings EHA to a new audience, which will bring new opportunities for fresh analysis of popular scientific writing of the Empire. 